\title{
Adversative Conjunction Kuseni in Japanese Language
}

\author{
Elizabeth Ika Hesti Aprilia Nindya Rini*, Vita Rahmadanti \\ Universitas Diponegoro, Semarang, Indonesia \\ *Email: elizabethikahesti@lecturer.undip.ac.id
}

\begin{abstract}
Kuseni is a conjunction used to connect contradictory clauses called as gyakusetsu no setsuzokushi in Japanese. This study aims to determine the structure and meaning of kuseni conjunction in Japanese sentences. The data source in this research is a sentence that contains a junction of conjunction, taken from several Japanese language websites. This study employs qualitative descriptive research. The result concludes that kuseni is an adversative conjunction that connects contradictory clauses containing criticism or reproach. Kuseni can be placed in the middle and the end of sentences and can be attached to the class of verbs, nouns, and adjectives in a sentence.
\end{abstract}

Keywords: setsuzokushi, adversative conjunction, kuseni

\section{Introduction}

Setsuzokushi (conjunction) is a word of class (part of speech) that has functions to connect words with words, clauses with clauses, or sentences with sentences, or also between paragraphs and paragraphs. From seven types of conjunctions in the Japanese language, conjunctions that express contradictory or called gyakusetsu no setsuzokushi in Japanese will be examined. There are several gyakusetsu no setsuzokushi in Japanese that have similar meanings, including ga, shikashi, noni, temo, nagara; therefore, Japanese language learners need to understand their usage properly. Hence, the author will discuss the kuseni conjunction to provide a clear description of its use in Japanese sentences.

Previous research that is relevant to this research is Wahidah's research (2016) titled, "Analysis of the Meaning of Conjunction nagara, noni, and kuseni in Sentences Expressing Opposition in Japanese." This study discusses the equation of the use of nagara, noni, and kuseni and analyzes whether the three conjunctions can be used interchangeably in the same sentences or not. Their study concluded that sentences using nagara and noni conjunction could be applied to oneself or others, on the other hand, kuseni conjunctions can only be applied to other people. This study found that nagara and noni conjunctions can replace one another; on the other hand, noni and kuseni conjunctions can also replace each other but produce different nuances of meaning in sentences. The three conjunctions can replace each other depending on the context of the sentence. The relevance of this research to Wahidah's is the object (kuseni conjunction.) However, this study does not compare other conjunctions but only discusses kuseni conjunction in terms of structure and meaning in further details.

Another relevant research to this research is Novita Sari's study (2017) titled, "Analysis of Contrastive Meaning in the Conjunction of $G a$ and Demo in the Short Stories of Nagi Keishi's Work." Novita Sari's research aims to describe the different meanings of the conjunctions in the short story of Kusa Suberi by Nagi Keishi. The study found that $g a$ 
IZUMI, Volume 9 No 1, 2020, [Page | 105]

e-ISSN: 2502-3535, p-ISSN: 2338-249X

Available online at: http://ejournal.undip.ac.id/index.php/izumi

conjunction has three meanings: expressing and absolute contradiction, stating a comparison of meanings, and stating the differences between the meanings of the clause. The conjunction of the demo shows two meanings: the opposition to the ideational meaning with the previous sentence and the state of what the speaker is doing without any contextual influence from the previous sentence. The difference of this study over Novita Sari's research relies on the situation where the object is added to the kuseni conjunctions discussion to enrich the understanding of adversative conjunctions (contradictory conjunction.)

\section{Methods}

This research is qualitative research since it does not employ numbers or variables that must be proven by testing the hypothesis but through the answers. Data sources from this research are Japanese websites: $\quad$ www.yourei.jp; www.yomiuri.japan; www.j-nihongo.com; and www.aozora.gr.jp. The method used for data collection is a 'simak bebas libat catat' method by observing and understanding sentences which contain kuseni conjunctions. By using simak bebas libat catat's method, the researcher only acts as an observer in the use of language from the informants or written sources. After obtaining data from various sources, the next step is to record the use of kuseni conjunction using the 'catat' technique.

Analysis of the data in this study uses the 'agih' method. The 'agih (distribution)' method is an analytical method in which the determinant tool is part of the language itself (Sudaryanto, 1993:15). The basic technique used in 'agih (the distribution)' method is the BUL (Bagi Unsur Langsung) technique that divides the lingual unit of data into several parts or elements to identify its structure and meaning.
The presentation of research data uses 'informal' methods, where the result and discussion employ common and understandable words.

\section{Result and Discussion}

Yamada stated that 'setsuzokushi wa bun to bun no ronrikankei o meikaku ni shi, tekisetsuni mochiiru koto de kikite no rikai o tasukeru.' This sentence means that conjunction is a class of words that clarifies the logical connection between clauses with proper use that will help the other people to understand the meaning of the sentence.

Kuseni is gyakusetsu no setsuzokushi (adversative conjunction), which is used to connect two clauses, namely the main clause and the subordinate clause that have a different connection. Shimomura (1988:63) states that 「前件から考えてそ うするのが変だとかおかしいというよ うな文があとに続く。のにより相手を 非難したり軽霡事る意味が強く、改ま った場合には使わない。」 which means: a sentence with kuseni conjunction considers what is stated in the subordinate clause; as a consequence, it becomes strange or funny to do things as stated in the main clause.

Asano (1994: 293) added that the kuseni conjunction showed an unexpected thing and had the nuances of the contradiction between main clauses and subordinate clauses that were stronger than sentences with noni conjunctions. Besides, compared to noni conjunction, kuseni has a stronger meaning to criticize and insult the interlocutor; hence it is not used in formal situations. In the Indonesian language, kuseni is paired with the word 'padahal.'

According to the KBBI (the Great Dictionary of the Indonesian Language of the Language Center), 'padahal' is a conjunction that shows a contradiction between the parts that are connected. 
In terms of structure, kuseni conjunction can be placed in the middle or the end of sentences and can be attached to verbs, nouns, and adjectives. Also, a sentence with kuseni conjunction must be having the same subject.

\subsection{Kuseni in the Middle of Sentences}

According to Kawashima (1999: 82), kuseni conjunction in the middle of the sentence is used to show criticism against things that are contrary to the norms or habits in society. The following are examples of sentences containing kuseni conjunction in the middle of a sentence.

a) 昨日まで見習いだったくせに大きい な口をきくな。(Makino, 1995:156)

Kinou made minaraidatta kuseni ookiina kuchi o kikuna.

"Jangan mulut besar, padahal (kamu) cuma peserta magang saja sampai kemarin."

Do not be a big mouth when you were just a yesterday's apprentice.

b) 彼は大学生のくせに、また母親に洗濯 してもらっているんだって。

(Kawashima, 1999:82)

Kare wa daigakusei no kuseni mata haha oya ni sentakushite moratteirundatte.

"Katanya dia masih meminta ibunya untuk mencuci pakaian, padahal (sudah) mahasiswa."

Even though he is a college student, his mother is doing his laundry.

In the above samples, kuseni conjunction positions are in the middle of the sentence following the subordinate clause. Kuseni expresses criticism against things that are not following the norms or habits in society. In sample a), kuseni follows the kinou made minaraidatta nominal kuseni clause 'however he/she was only a yesterday's apprentice.' That sentence contained the meaning of critics upon the subject who acted arrogantly even though he had just completed yesterday's internship implicitly. According to the speaker, an apprentice still did not have much experience, and it was not appropriate to have a big mouth. In sentence b), kuseni follows the nominal clause of kare wa daigakusei no kuseni 'even though he is a student.' Implicitly, there is a critic to the subject because the mother still assisted him in personal matters when an adult usually can take care of his business.

\subsection{Kuseni at the end of the sentences}

Kuseni conjunction at the end of the sentence is used to show the meaning of denouncing an unusual or strange thing to do. Examples of sentences are as follows:

c) あなただってできないくせに... (Chino, 2001:95)

\section{Anatadatte dekinai kuseni.}

"Padahal kamu sendiri saja tidak bisa."

Still, you cannot do it.

d) 何だ、何も知らないくせに!

(Kawashima, 1999:83)

Nanda nanimo shiranai kuseni.

"Apa, padahal (kamu) tidak tahu apapun!"

What, (you) know nothing, though!

For example, in sentences c) and d), kuseni conjunction is placed at the end of the sentence and shows the meaning of reproach. In sentence c), kuseni conjunction follows the verbal clause anata datte dekinai kuseni 'still you cannot do it by yourself.' In sentence d), kuseni conjunction follows the verbal clause nanda nanimi shiranai kuseni '(you) know nothing, though.' In sentences c) and d), even though the main clause is not said explicitly, the contents can be predicted.

According to the above explanation, kuseni conjunction is divided into two types in terms of structure position: kuseni in the middle of the sentence and kuseni at the end of the sentence. The following is examples of data analysis: 


\subsection{Kuseni Conjunction Located in the Middle of Sentence}

(1) 絵のことなんか知らないくせに、勝手 なこと言わないで!

(www.aozora.gr.jp)

E no koto nanka shiranai kuseni kattena koto iwanaide!

"Jangan berbicara semaumu sendiri, padahal kamu saja tidak tahu apapun tentang lukisan."

Do not say anything when you know nothing about painting!

In sentence (1), kuseni is attached to the negative verb shiranai 'know nothing' in the verbal clause $e$ no koto nanka shiranai kuseni 'when he does not know anything about painting.' Kuseni in sentence (1) is located in the middle of the sentence and connects subordinate clauses e no koto nanka shiranai 'know nothing about the painting' with the main clause kattena koto iwanaide 'do not say anything at all.' Kuseni in that sentence has an implied meaning in the form of criticism against a subject who said something about a painting frivolously; what makes the speaker feel annoyed is the subject does not understand anything about the painting.

(2) 就職したことがないくせにそんなことを 知っているのが不思議でならない。 (yourei.jp)

Shuushoku shita koto ga nai kuseni sonna koto o shitte iru no ga fushigi de naranai.

"Sangat mengherankan dia mengetahui hal seperti itu, padahal dia belum pernah bekerja."

It is strange that you know such things even though you have not had a job.

In sentence (2), kuseni is attached to the verbal clause shuushoku shita koto ga nai kuseni 'even though he has not worked.' Kuseni connects the main clause sonna koto o shitte iru no fushigi de naranai 'it is very surprising that he knows such things' with the subordinate clause shuushoku shita koto ga nai kuseni 'even though he has never worked.' The kuseni conjunction in sentence (2) shows the speaker's surprise over the subject who can understand such things even though he has never worked.

（3）彼はお金がたくさんあるくせに、全然 ごちそうしてくれない。

(www.j-nihongo.com)

Kare wa okane ga takusan aru kuseni zenzen gochisoushite kurenai.

"Padahal dia punya uang banyak, tapi sama sekali tidak pernah mentraktir."

Even though he has a lot of money, he has never given us treat at all.

In sentence (3), kuseni is attached to the verb aru 'exist' in verbal subordinate clauses kare wa okane ga takusan aru kuseni 'even though he has much money.' Kuseni connects the main clause zenzen gochisoushite kurenai 'never gave us treat at all' with subordinate clauses kare wa okane ga takusan aru 'he has a lot of money.' Kuseni in sentence (3) shows the meaning of criticism of subject kare. This sentence contained criticism against the attitude of the subject kare who is considered stingy despite having much money.

（4）私は日本人のくせに日本語の文法が 大嫌いだ. (http://www.j-nihongo.org)

Watashi wa Nihonjin no kuseni nihongo no bunpou ga daikiraida.

"Padahal orang Jepang, tapi saya sangat membenci tata bahasa Jepang."

I hate Japanese grammar despite the fact that I am Japanese.

In sentence (4), kuseni is attached to the noun 'Japanese' nihonjin in the nominal clause watashi wa nihonjin no kuseni 'even though I am Japanese.' Kuseni is in the middle of the sentence and connects the subordinate clause watashi wa nihon jin 'I am Japanese' and the main clause nihongo no bunpou ga daikiraida 'really hates Japanese grammar.' Kuseni in sentence (4) contains the meaning of self-criticism. The subject's statement is contradictory; Japanese people should not hate Japanese 
grammar since they are Japanese native speakers.

This sample contradicts Wahidah's previous research stating that kuseni could not be intended for oneself.

（5）先生こそ婦人科が専門のくせに、そん なこと御存じないんですか。 (yourei.jp)

Sensei koso fujinka ga senmon no kuseni, sonna koto gosonji naindesuka. "Padahal spesialisasi dokter adalah ginekologi, Apakah (anda) tidak mengetahui mengenai hal itu?"

Even though you are a doctor who specializes is in gynecology, do you not know about that?

In sentence (5), kuseni is attached to the noun senmon 'specialization' in the nominal clause sensei koso fujinka ga senmon no kuseni 'even though you are a doctor who specializes in gynecology.' Kuseni is placed in the middle of the sentence and connects the subordinate clause sensei koso fujinka ga senmon with the main clause sonna koto gosonji naindesuka 'do (you) not know about it?' Sentence (5) implies critics to the doctor who does not know what the speaker is talking about although he specializes in gynecology. According to the speaker, like gynecology, the subject should understand about his specialization.

(6) あの女は五十に近いくせに、寝るとき に化粧なんかしているんですからね。 (www.yourei.jp)

Ano onna wa gojuu ni chikai kuseni, neru toki ni keshou nanka shiteirundesukara ne.

"Karena wanita itu ketika tidur dalam kondisi berdandan, padahal umurnya (sudah) mendekati 50 tahun."

Even though her age is close to fifty years old, she wears makeup while sleeping.

In sentence (6), kuseni adheres to the adjunctive clause ano onna wa gojuu ni chikai 'even though she is close to 50 years old.' Kuseni connects the main clause neru toki ni keshou nanka shiteirun desukare 'because she wears makeup when she sleeps' with the subordinate clause ano onna wa gojuu ni chikai 'she is close to 50 years old.' The use of kuseni conjunction in sentence (6) implies the meaning of the astonished speaker who does not expect an older woman was wearing makeup before sleeping. Generally, an elderly does not care much about her physical appearance, especially during sleep.

（7）私なんかよりもっと大きなくせに、それ 随分出来ない娘がいるんですもの。

(www.asahi.com)

Watashi nanka yori motto ookina kuseni, sore zuibun dekinai musume ga irundesumono.

"Karena mempunyai anak perempuan yang lumayan tidak bisa melakukannya, padahal ia lebih besar daripada saya."

I have a daughter who cannot do much, even though she is bigger than me.

In sentence (7), kuseni is attached to the adjunctive clause ookina 'big' watashi nanka yori motto ookiina kuseni 'even though she is bigger than me.' Kuseni is located in the middle of the sentence and connects the main clause sore zuibun dekinai musume ga irundesumono

'I have a daughter who cannot do much' with the subordinate clause watashi nanka yori motto ookiina 'she is bigger than me.' Kuseni in the sentence expressed the speaker's strange feelings towards his daughter, who could not do things that should have been done by girls as big as her.

\subsection{Kuseni Conjunction Located at the End of the Sentence}

(8) 自分で世話もできないくせに ... (www.yomiuri.jp)

Jibunde sewa mo dekinai $\underline{\text { kuseni.... }}$ 
"Padahal (kamu) saja tidak bisa mengurusnya sendiri..."

Even though he cannot take care of it by himself...

In sentence (8), kuseni is attached to the negative verb dekinai 'cannot' in the verbal clause jibun de sewa mo dekinai kuseni 'even though he cannot take care of it by himself.' Kuseni is located at the end of the sentence following the subordinate clause of jibun de sewa mo dekinai 'cannot take care of it.' In sentence (8), the main clause is omitted, but the overall meaning of the sentence can be predicted. Kuseni in sentence (8) shows the implied meaning of insults to subjects who are considered unable to take care of something but keep commenting on people's work.

（9）そしらぬ顔をして，しってるくせに! (www.yomiuri.jp)

Soshiranu kao o shite shitteru kuseni!

"Padahal (kamu) tahu kan, tapi menunjukkan wajah pura-pura tidak tahu!"

You show an innocent face even though (you) know!

In sentence (9), kuseni is attached to -teiru form verb shitteiru 'know' in the verbal clause of soshiranu kao o shite shitteiru kuseni 'even though (you) know, you pretend like you don't know anything.' Kuseni is located at the end of the sentence and follows the subordinate clause of soshiranu kao o shite, shitteru 'knows but shows a face of not knowing.' Kuseni in the sentence implies the speaker's strange feeling about the subject who is pretending not to know even though he knows the truth.

(10) 寝不足が聞いて呆れるよ。ゆうべはあ んなにグウグウ眠ってたくせに！

(www.yourei.jp)

Nebusoku ga kite akireru yo. Yuube wa anna ni guи guи nemutte ita kuseni!

"(Saya) terkejut ketika kau mengatakan kurang tidur. Padahal tadi malam (kamu) tidur lelap sambil mendengkur."

I am amazed when I hear you suffer from lack of sleep. Even though last night I heard

You were snoring!

In sentence (10), kuseni is attached to the te ita form verb nemutte ita 'deep sleep' in the verbal clause yuube wa anna ni guu guи nemutte ita kuseni 'even though last night (you) slept well and snored.' Kuseni is located at the end of the sentence and follows the verbal subordinate clause yuube wa anna ni guи guи nemutte ita kuseni 'even though last night (you) were snoring while sleeping.' Kuseni in the sentence means the speaker's strange feeling to the subject who said that he lacked sleep, whereas the speaker knows the subject was snoring while sleeping.

（11）借金をすると僕に後始末を頼むくせ に... (www.yourei.jp)

Shakkin o suru to boku ni atoshimatsu o tanomu kuseni.

"Padahal kalau meminjam uang, (kamu) meminta padaku untuk menyelesaikannya."

When you go into debt, you ask me to clean it up...

In sentence (11), the kuseni is attached to the verb tanomu 'beg' in the verbal clause shakkin o suru to boku ni atoshimatsu o tanomu 'if you owe money, you ask me to settle it.' Kuseni is located at the end of the sentence following the subordinate clause shakkin o suru to boku ni atoshimatsu o tanomu 'begging me to settle if you go into debt.' Kuseni in sentence (11) means an insult to the subject who is arrogant; when he is experiencing difficulties, he begs someone to help. (12)お前なんか、まだ歯も抜けていないガ キのくせに... (www.asahi.com)

Omae nanka mada ha mo nuketeinai gaki no $\underline{\text { kuseni }}$... 
"Padahal kamu itu anak kecil nakal yang giginya saja masih belum tanggal."

However, you are just a kid who has not lost any teeth yet.

In sentence (12), kuseni is attached to the noun gaki 'naughty boy' in the nominal clause omae nanka mada ha mo nuketeinai gaki no kuseni 'however, you are just a bad boy whose teeth are still not fixed in place.' Kuseni is located at the end of the sentence and follows the subordinate clause of omae nanka mada ha mo nuketeinai gaki 'bad boy whose teeth are still not settled.' Kuseni in sentence (12) means an insult to the subject omae 'you.' In sentence (12), it is implied that the speaker is underestimating a person who is considered a naughty child with a runny nose; therefore, he is not eligible to interfere with an adult's business.

(13) おかしいわ、男のくせに。

(www.yourei.jp)

Okashii wa, otoko no kuseni.

"Aneh ya, padahal (dia) seorang lakilaki."

It is funny to the habit of a man.

In sentence (13), kuseni is attached to the noun otoko 'laki-laki' in the nominal clause of okashiiwa, otoko no kuseni is 'weird, even though (he is) a man.' Kuseni is located at the end of the sentence and follows the subordinate clause okashiiwa, otoko no kuseni 'strange, even though (he is) a man.' Kuseni in sentence (13) means an insult to the subject who does things that are not normally done by a man.

(14) オレから見ればほんのまだ赤ん坊の くせに! (www.yourei.jp)

Ore kara mireba hon no mada akanbou no kuseni!

"Padahal dari sudut pandang saya (dia) benar-benar masih bayi."

However, from my point of view, he is just a baby!

In sentence (14), kuseni is attached to the noun akachan 'baby' in the nominal clause of ore kara mireba hon no mada akanbou kuseni! 'However, from my point of view (he) is a baby.' Kuseni is located at the end of the sentence and follows the subordinate clause of ore kara mireba hon no mada akanbou no kuseni! 'However, (he) is just a baby from my point of view.' Kuseni in sentence (14) means an insult to the subject; the speaker thinks the opponent is still 'a baby' or immature to do things as he had done.

(15) 自分の恋には臆病なくせに ... (www.yourei.jp)

Jibun no koi ni wa okubyouna kuseni...

"Padahal (kamu) seorang pengecut dalam percintaanmu sendiri."

In fact, you are timid in your love

In sentence (15), kuseni is attached to the adjective na okubyouna 'timid' in the adjectival clause jibun no koi ni wa okubyouna 'you are timid in your love.' Kuseni follows the clause of jibun no koi ni wa okubyouna 'timid in your love.' Kuseni in sentence (15) implies an insult to the subject who comments about people's love but is not brave enough for his love. 'Timid' or 'coward' is an insult intended for people who are hesitant or timid about doing something that might get a negative response from others.

(16) 本当は、怖いくせに。 (www.yourei.jp)

Hontou wa, kowai kuseni.

"Padahal sesungguhnya, (dia) takut." In fact, he is scared

In sentence (16), kuseni adheres to the adjective $i$ kowai 'fear' in the adjective clause, hontou wa kowai 'you are actually afraid.' Kuseni follows the subordinate clause of hontou wa, kowai kuseni 'in fact he is afraid.' The kuseni in sentence (16) implies an insult to the subject who acts as if he was brave when he was actually scared. 
IZUMI, Volume 9 No 1, 2020, [Page | 111]

e-ISSN: 2502-3535, p-ISSN: 2338-249X

Available online at: http://ejournal.undip.ac.id/index.php/izumi

\section{Conclusions}

Based on the analysis, Kuseni conjunction is a conjunction whose position can be placed in the middle or end of a sentence. This conjunction can be attached to word class of verb $\quad(-r u)(-t e$ iru), (-ta), (-te ita), (-nai) + kuseni, adjective-i $+k u$ seni, adjective $-n a+k u s e n i$, and nouns + no + kuseni.

Kuseni conjunction states the meaning of contradiction because there is a mismatch between subject behaviors and habits or norms that exist in society. Sentences with kuseni conjunctions express criticism or reproach of unusual or strange habits perceived by the speaker.

\section{References}

Asano, Tsuruko. (1990). Gaikokujin no Tame no Kihongo Yourei Jiten. Tokyo: Bunkacho

Chaer, Abdul. (1990). Pengantar Semantik Bahasa Indonesia. Jakarta: Rineka Cipta.

Chaer, Abdul. (1994). Linguistik Umum. Jakarta: Rineka Cipta.

Chino, Naoko. (2001). All About Particles. Tokyo: Kodansha Inc.

Iori, Isao. (2000). Nihongo Bunpou Handobukku. Japan: 3A Network.

Inagaki, Hanako et al. (2008). Nihon Go Hyougen Bunkei Jiten. Japan: Ask Publishing.

Jamashii, et al. (1998). Nihongo Bunkei Jiten. Tokyo: Kuroshio Shuppan.

Kridalaksana, Harimurti. (1994). Kelas Kata dalam Bahasa Indonesia. Jakarta: Gramedia Pustaka Utama.

Lehrer, Andriene. (1974). Semantics Fileds and Lexical Structure. Amsterdam: North Holland Publ.

Makino, Tsutsui. (2008). A Dictionary Of Advanced Japanese Grammar. Tokyo: The Japan Times.

Matsumiya, Yahei. (1935). A Grammar of Spoken Japanese. Tokyo: Kyo Bun Kwan.
Pateda, Mansoer. (2010). Semantik Leksikal. Jakarta: Rineka Cipta.

Satoshi, Mitsuko et al. (1998). Nihon Go no Bunkei Jiten. Japan: Kuroshio Publishing.

Sudaryanto. (1993). Metode dan Aneka Teknik Analisis Bahasa. Yogyakarta: Duta Wacana University Press.

Sudjianto dan Dahidi. (2004). Pengantar Linguistik Bahasa Jepang. Jakarta: Kesaint Blanc.

Sunagawa, Yuriko, et al. (2002). Nihongo Bunkei Jiten. Tokyo: Kuroshio Shuppan.

Ullman, Stephen. (1972). Semantics an Introduction to the Science of Meaning. Oxford: Basil Blackwell.

Yamada, Toshihiro. (2004). Kokugo Kyoushi ga Shitteokitai Nihongo Bunpou. Tokyo: Kuroshio Shuppan.

Electronic Referral:

www.aozora.gr.jp [downloaded in $12 / 2 / 2019]$

www.j-nihongo.com [downloaded in 3/11/2019]

www.yomiuri.japan [downloaded in $10 / 1 / 2020]$

www.yourei.jp [downloaded in 2/2/2020] www.repository.upi.edu/25739/

[downloaded in 12/2/2019]

www.ejournal.undiksha.ac.id/index.php/JJ $\mathrm{PBJ} /$ article/view/12144 [downloaded in 12/2/2019] 